\title{
AN ANTHOLOGY OF THE DISTINGUISHED ACHIEVEMENTS IN SCIENCE AND TECHNIQUE. PART 47: AIRCRAFT DESIGNER IGOR SIKORSKY AND HIS ACCOMPLISHMENTS IN DESIGN OF AIRPLANES AND HELICOPTERS
}

Purpose. Preparation of short scientifically-historical essay about one of founders of world aviation, prominent Ukrainian and American aircraft designer I.I. Sikorsky. Methodology. Known scientific methods of collection, analysis and analytical treatment of scientific and technical information, touching becoming and development of world aviation and resulted in scientific monographs, journals and internet-reports. Results. A short scientifically-historical essay about a prominent Ukrainian and American aircraft designer Igor Ivanovich Sikorsky, becoming one of founders of world aviation. Basic scientific and technical achievements of I.I. Sikorsky in an area of design of airplanes and helicopters, emigrating because of overcame civil war from Russia to the USA (1919). It is shown that I.I. Sikorsky is the founder of not only American but also domestic aviation industry. I.I. Sikorsky became the first on our planet incarnating in reality the dream of the genius Italian inventor Leonardo da Vinci on creation of helicopter. He became the "father" of world design of helicopters. By him in Russia and the USA 17 base types of airplanes and 18 base types of helicopters were developed and built, operating on piston and gas-turbine engines. Helicopters development by I.I. Sikorsky firstly the world accomplished flying (with refuelling in mid air) over Atlantic (S-61, 1967) and pacific (S-65, 1970) oceans. It is marked that one of reliability indexes of the designs of aircrafts created by him is that until now the Presidents of the USA fly on helicopters with inscription of "Sikorsky" onboard. Originality. Certain systematization is executed known from scientific publications and other mass of scientific and technical materials media, touching becoming and development of world aviation and contribution to world design of airplanes and helicopters of prominent Ukrainian and American aircraft designer I.I. Sikorsky. Practical value. Scientific popularization and deepening for University students, engineering, technical and scientific workers of scientific and technical knowledge in the field of history of becoming and development of world design of airplanes and helicopters, extending their scientific and technical range of interests and further development of scientific and technical progress in society. References 12, figures 12.

Key words: aviation, prominent Ukrainian and American aircraft designer Igor Sikorsky, basic achievements in construction of airplanes and helicopters, scientifically-historical essay.

Наведено короткий науково-історичний нарис про видатного украйнсько-американського авіаконструктора Ігоря Івановича Сікорського, якій став одним з основоположників світової авіації. Описані основні досягнення I.I. Сік орського в галузі літако- і вертолітобудування, цчо емігрував із охопленою громадянською війною Росї̈ в США (1919 р.). Показано, щцо І.І. Сікорський є засновникам не тільки американської, але і вітчизняної авіаційної промисловості. I.I. Сікорський став периою на нашій планеті людиною, яка утілила в реальність мрію геніального італійського винахідника Леонардо да Вінчі по створенню вертольота. Бібл. 12, рис. 12.

Ключові слова: авіація, видатний українсько-американський авіаконструктор Ігор Сікорський, основні досягнення в літако- і вертолітобудуванні, науково-історичний нарис.

Приведен краткий научно-исторический очерк о выдающемся украинско-американском авиаконструкторе Игоре Ивановиче Сикорском, ставщем одним из основоположсников мировой авиации. Описаны основные достижения И.И. Сикорского в области самолето- и вертолетостроения, эмигрировавщего из охваченной гражданской войной России в США (1919 2.). Показано, что И.И. Сикорский является основателям не только американской, но и отечественной авиационной промышленности. И.И. Сикорский стал первым на нашей планете человеком, воплотившим в реальность мечту гениального итальянского изобретателя Леонардо да Винчи по созданию вертолета. Библ. 12, рис. 12.

Ключевые слова: авиация, выдающийся украинско-американский авиаконструктор Игорь Сикорский, основные достижения в самолето- и вертолетостроении, научно-исторический очерк.

Introduction. In the history of mankind there are many talented personalities who brought one or another area of scientific and technical knowledge to a new higher level of their development. One of these personalities was our compatriot Igor Ivanovich Sikorsky (Fig. 1), who became the largest aircraft designer of the 20th century [1]. Many outstanding achievements of design thought in world aviation are connected with his name. It should be noted that the beginning of the development of aircraft industry in the Russian Empire is closely related to the talent of this person. A significant part of that in aviation, which made by a Ukrainian by origin I.I. Sikorsky, associated with the development of design of aircrafts and helicopters in the USA [1,2]. Paying tribute to this outstanding Ukrainian-American aircraft designer, we will try in the form of a brief scientific and historical essay to trace his life and career in aviation.

The goal of the paper is preparation of a brief scientific and historical essay on one of the founders of world aviation, an outstanding Ukrainian-American aircraft designer I.I. Sikorsky.

1. The beginning of the life and career. The hero of our essay was born on May 25, 1889 in the family of a Doctor of Medicine, Professor at Saint-Vladimir Kyiv University Ivan Alekseevich Sikorsky, known in the Russian Empire and abroad for his many publications on psychiatry [1]. The father raised his younger son (Igor was the fifth child in the family) according to his own methodology in devotion to the Church, the Throne and 


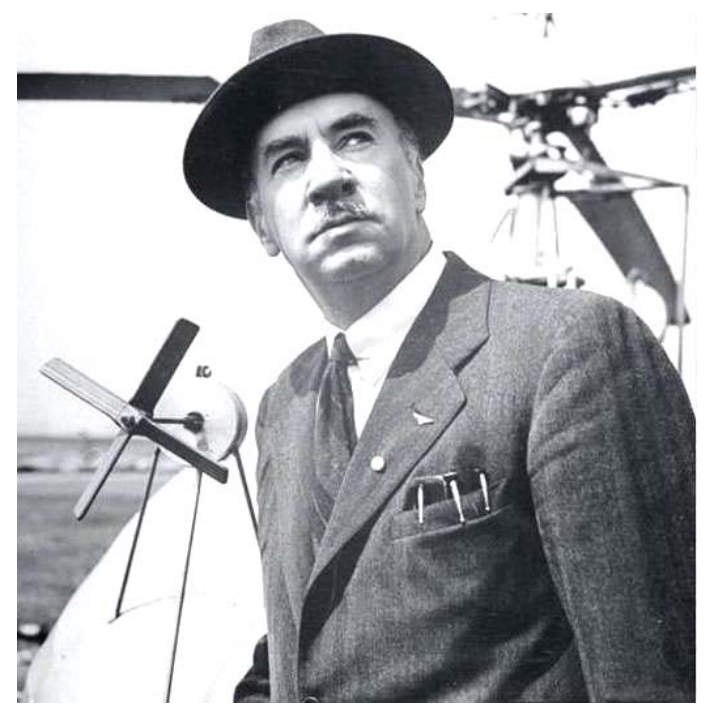

Fig. 1. Outstanding aircraft designer of the 20th century Igor Ivanovich Sikorsky $(25.05 .1889-26.10 .1972)[2]$

the Fatherland. He managed to develop in him an unshakable will and instill in him a unique perseverance in achieving his noble goal [1]. The mother of the future aircraft designer, Maria Stefanovna (nee TemryukCherkasova), who was a medical doctor by training (by profession due to domestic chores and raising children she did not work), instilled in Igor a love of music, literature and art. He began studying at the 1st Kyiv Gymnasium, and in 1903 he wished to continue his education at the Naval Cadet Corps (Saint Petersburg). At the end of general education classes, he leaves this Corps in order to obtain higher technical education. Young I.I. Sikorsky, in order to realize his true vocation, in 1906 moves to Paris and entered the Duvigne de Lannoy Technical School [1]. After studying at this school for just one year, in 1907, due to the death of his mother, he returned to Kyiv and entered the Mechanical Department of the Emperor Alexander II Kyiv Polytechnic Institute (KPI). Successfully completing the first academic year at the KPI, I.I. Sikorsky decided to do practical work in his own workshop for the development and creation of aircrafts [1]. It should be noted that the KPI, founded in 1898, was a higher technical school of Russia of a new type, where students received deep natural-science fundamental training in mathematics, physics, chemistry and other disciplines on which general engineering courses were built [4]. Training of students at the KPI was combined with professional and practical work in industry and in scientific laboratories. The KPI strongly encouraged research and practical work of teachers and students in specialized research groups at the Institute. The idea of building an aircraft of his own design fully captured the young and promising young man in the field of domestic aircraft industry I.I. Sikorsky, who forgot about his studies at the KPI for the time being (the period of his studies at the KPI is considered to be the period of 19071911 [3]). His first experiments on the creation of a helicopter ended in failure. Soberly assessing the situation, he decided to postpone work on creating his own helicopter until better times and start developing airplanes with a fixed wing. For the period 1910-1911, he created with his own money five types of biplanes of the
S-1 - S-5 series with an internal combustion engine of power from 15 to $50 \mathrm{hp}$. (Fig. 2). Having reached the height of a flight of 450 meters on an S-5 type biplane and time in the air of about 1 hour, the aircraft designer I.I. Sikorsky gained world fame [4].

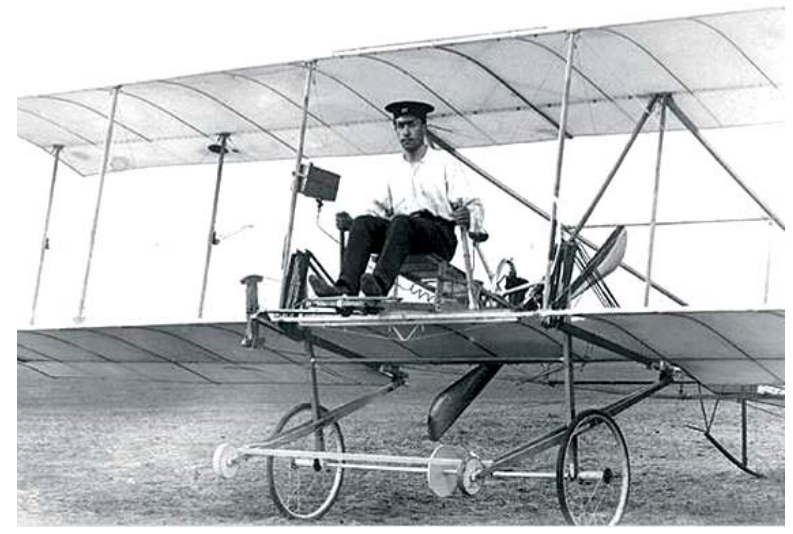

Fig. 2. Young aircraft designer I.I. Sikorsky on his one of the first airplanes of type S-2 (1910, Kyiv) [2]

2. Major achievements of the aircraft designer I.I. Sikorsky in airplane industry. In December 1911, on a biplane of his own design of the type S-6 with an engine of $100 \mathrm{hp}$, I.I. Sikorsky set the world record for aircraft speed in airspace $-111 \mathrm{~km} / \mathrm{h}$ [5]. From 1912 to 1917 a student Igor Sikorsky, who did not finish his study at the KPI, held a high position as chief designer of the Aviation Department of the Russian-Baltic plant in Saint Petersburg (later renamed by the forces of the Russian revolutionary movement in Petrograd), which supplied the airplanes for the Russian army [1]. It is interesting to note that in 1914, for his outstanding achievements in the field of Russian military aircraft manufacturing, I.I. Sikorsky received an Engineering Diploma from the Saint Petersburg Polytechnic Institute, which became under Soviet rule known throughout the world as the Leningrad Polytechnic Institute (now this educational institution is called Saint Petersburg Technical University). It is at this Russian plant I.I. Sikorsky creates the first in the world multi-engine heavy airplanes «Russian Knight» and «Ilya Muromets» (Fig. 3). His biplanes and monoplanes brought Russia fame as one of the world's leading aviation powers.

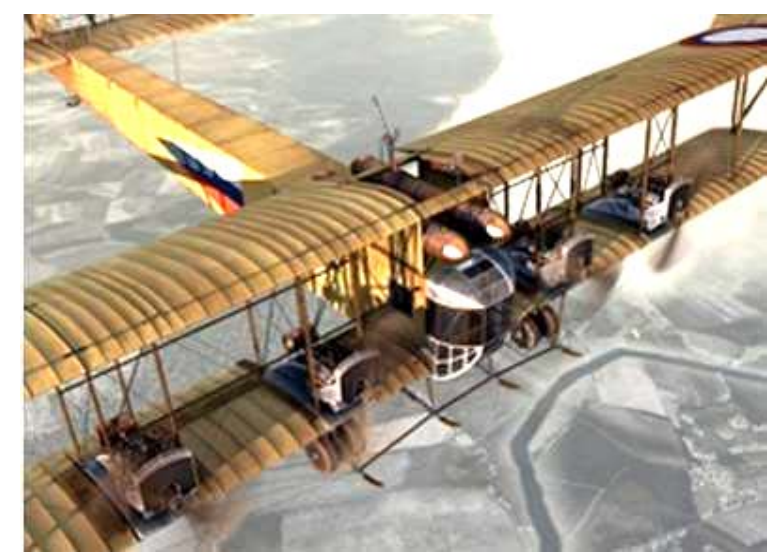

Fig. 3. Four-engine bomber «Ilya Muromets» (S-22) of military transport purpose developed by I.I. Sikorsky (1913, Saint Petersburg, Russia) [2] 
However, in 1918, the talented aircraft designer who had done so much for the development of Russian aviation, a former senior student of the KPI Igor Sikorsky, who had escaped from the Red Terror, was forced to leave Russia and sail by the English ship from Murmansk to France [19]. Having worked in Paris for about a year at one of the aircraft building factories, our young aircraft designer came to the fateful conclusion for him that there are more prospects for the development of heavy aircraft building across the ocean in America. Note that the aircraft designer I.I. Sikorsky, even before the start of World War I in 1914, firmly concluded that aviation would have a future for large aircrafts with two or more engines. In his opinion, such aircrafts over single-engine airplanes had clear advantages both in flight range and in transport capabilities. In addition, this type of aircrafts was safer than single-engine «brothers». In March 1919, he arrives (or rather sails) from Europe to North America to the seaport of New York - a large entrance «gate» for numerous immigrants from around the world. From now until the end of his long life, his unique intelligence and creative forces were largely entirely focused on the development of the American aviation industry, the protection and prosperity of his beloved family. After the usual initial hard ordeals and several years of severe survival in a foreign land, in 1923 the purposeful aircraft designer I.I. Sikorsky founded his first aircraft manufacturing Company, Sikorsky Aero Engineering Corporation, in the United States, developing and producing aircrafts [2]. The first aircraft produced by this American company was the passenger twin-engine biplane S-29 (Fig. 4) [2].

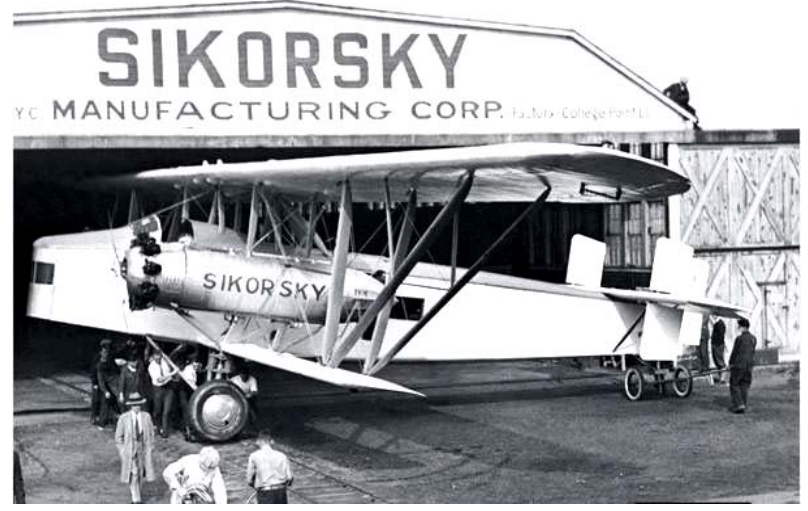

Fig. 4. One of the first twin-engine civilian type S-29 biplane airplane designed and developed by I.I. Sikorsky in the USA (1924) [2]

Life of I.I. Sikorsky in 1924 began to improve: from the former USSR two sisters and a grown daughter Tatiana from his first marriage came to him for permanent residence (his first wife refused to move to the United States). Soon, Igor Ivanovich entered into a second marriage with the Russian émigré Elizaveta Alekseevna Semenova. This marriage turned out to be happy for the Sikorsky couple: one after another, the sons Sergey, Nikolay, Igor and Georgy were born in their family [1]. At that time, their father stubbornly continued to promote his aircrafts on the American vehicle market. I.I. Sikorsky «discovers» for himself a niche in the aircraft industry unused in the United States - the production of amphibious aircrafts capable of taking off from the surface of the water and landing on it. In 1928, I.I. Sikorsky received US passport, and in 1929 his company became a branch of the larger American company United Aero Craft. At it, he holds the position of a design engineering manager for aircrafts [7]. This US aircraft manufacturing Company produces twin-engine ten-seat amphibious aircrafts of the S-38 type (Fig. 5) [1, 7].

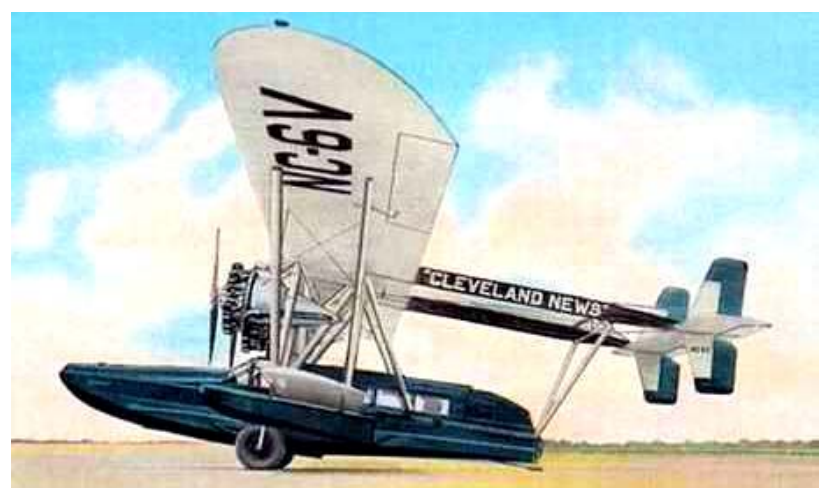

Fig. 5. Two-engine ten-seat amphibious aircraft of type S-38 developed by I.I. Sikorsky (1929, USA) [1]

In 1931 this flying «boat» by I.I. Sikorsky opened the post-passenger service in the zone of the Caribbean islands and to South America. By the summer of 1937, the «Pan American» Company on his four-engine amphibious aircraft of the S-42 type began to successfully serve the transpacific and transatlantic routes [7]. Later, these mainline aircrafts were replaced with his more comfortable and reliable flying «boats» of the S-44 type (Fig. 6).

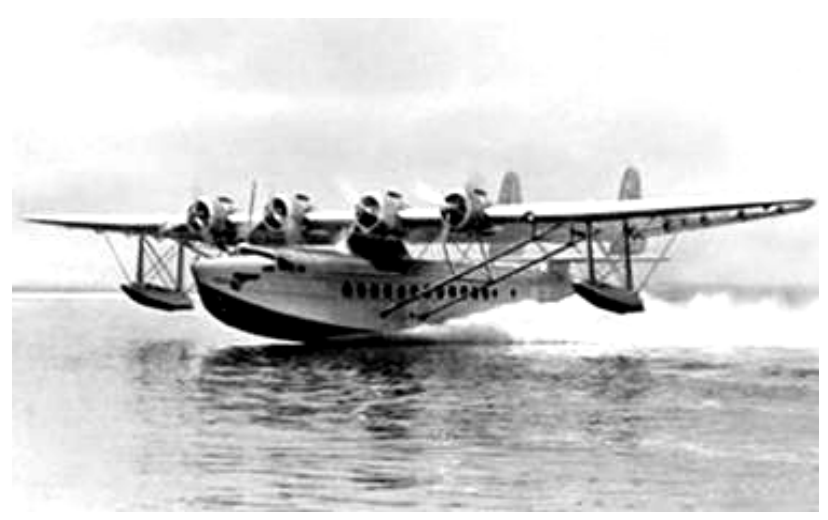

Fig. 6. Four-engine long-range fifty-passenger amphibious aircraft of type S-44 developed by aircraft designer I.I. Sikorsky (1937, USA) [2]

By 1939, I.I. Sikorsky developed and created 17 types of aircrafts in the «metal» [7]. In the late 1930s, due to a change in aviation commercial conjuncture for amphibious aircrafts, I.I. Sikorsky returns to the idea of building his own helicopter.

3. Major achievements of the aircraft designer I.I. Sikorsky in helicopter industry. At the end of 1938, I.I. Sikorsky, together with his assistants, began to develop a fundamentally new and at that time still unknown aircraft - a helicopter. So the great aircraft 
designer for the third time (for the first time - in Russia since 1910, and the second time - in the USA since 1924) practically from scratch begins his creative career in the aircraft industry. His first experimental helicopter of the VS-300 (S-46) type with an open tubular frame took off on September 14, 1939 under the control of the aircraft designer himself [1]. This helicopter had an original single-screw design scheme with an automatic blade skew and, accordingly, one lifting screw. To counteract the torque, resulting in a circular movement of the cockpit of the aircraft, on its tail a small screw with a mechanical drive from the engine of the main lifting screw was installed [1, 2]. At present, this single-rotor helicopter design scheme is considered to be classic. Since then, at least $90 \%$ of all helicopters in the world have been built on this base. Then, in 1939, many aircraft designers of the world considered this scheme unpromising. In 1942, I.I. Sikorsky created a double-seat helicopter of the «Sikorsky XR-4» or S-47 type (Fig. 7), which soon entered the USA serial production [2].

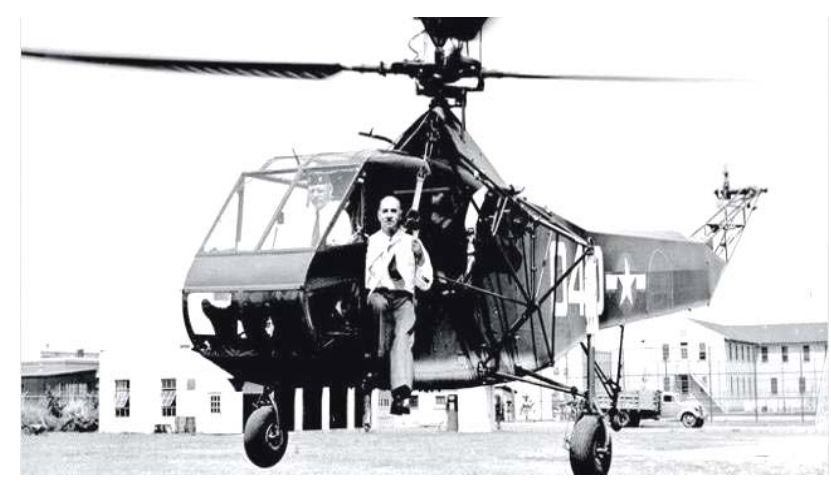

Fig. 7. Aircraft designer I.I. Sikorsky in the cockpit of his new technical «brainchild» - the world's first serial US helicopter type «Sikorsky XR-4» (1942, USA) [2]

This type of helicopter turned out to be the only helicopter of the countries of the anti-Hitler coalition during World War II. The aircraft manufacturer Sikorsky Aero Craft, which has become the leader in US helicopter manufacturing and was part of the large American company United Aero Craft, is once again gaining autonomy and a new production base in Bridgeport. Shares of this Company grew. Due to the large growth in production orders for helicopters, a new factory was built for their production in Stratford, where I.I. Sikorsky and moved his residence. As the main purpose of the helicopter, he considered the saving of human lives. In this regard, we quote the phrase he expressed [2]: «... I am sure that the helicopter will become a unique vehicle for saving lives». The S-52 light helicopter was the first helicopter in the world to perform aerobatics. In 1953, I.I. Sikorsky, using his single-rotor scheme, created a heavy helicopter with a lifting weight of 14 tons [2]. Successful use of combat helicopters designed by I.I. Sikorsky in the Korean War forced the leadership of the former USSR to pay close attention to the rotorcraft technique. So he indirectly influenced the development of the Soviet helicopter industry. The best helicopter created by
I.I. Sikorsky in 1954, is considered a passenger helicopter type S-58 (Fig. 8). In terms of its technical and economic characteristics, it surpassed all the helicopters of the world of its time [2].

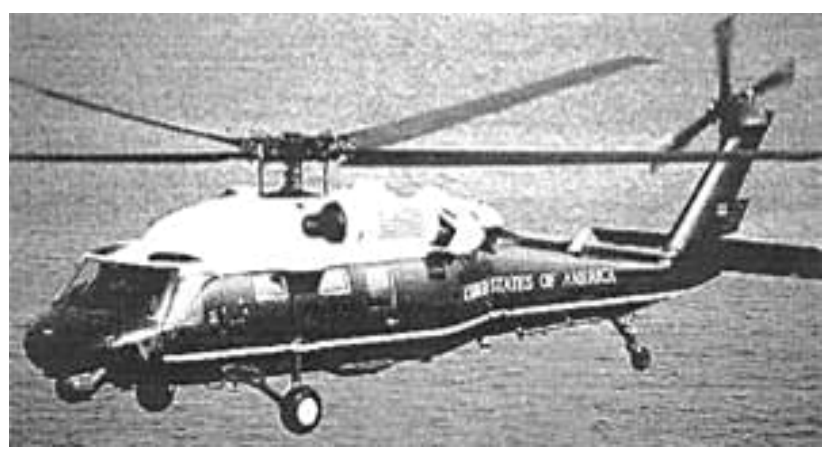

Fig. 8. Passenger helicopter type S-58 - the best design of the great aircraft designer I.I. Sikorsky,

which became for him a «swan song» (1954, USA) [2]

Fig. 9 shows a general view of a helicopter crane, designed and created by I.I. Sikorsky $[1,2]$.

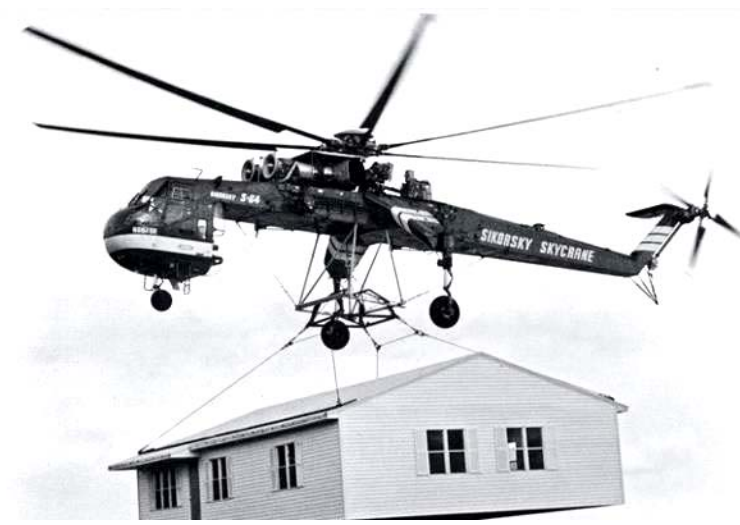

Fig. 9. General view of the helicopter crane development by aircraft designer I.I. Sikorsky, in operation (1950s, USA) [2]

Aircraft designer I.I. Sikorsky (Fig. 10), as the founder of the world helicopter industry, for many years remained at the unattainable scientific and technical «height». In addition to 17 types of airplanes developed and built in Russia and the United States, he created 18 basic types of helicopters in the United States [2]. During his life, I.I. Sikorsky received over 80 various honorary awards, prizes and diplomas. Among them are the Russian Order of Saint Vladimir of the 4th degree, gold medals of Daniel Guggenheim, James Watt and a Diploma from the National Gallery of Fame of Inventors. In 1948, he was awarded a rare award - the Wright Brothers Memorial Prize, and in 1967 he was awarded the John Fritz Medal of Honor for scientific and technical achievements in the field of basic and applied sciences [2]. Note that in world aviation only Orville Wright was awarded this medal before him as the founder of world aircraft design. Aircraft designer I.I. Sikorsky was elected an honorary Doctor of many leading Universities in the world $[2,7]$. 


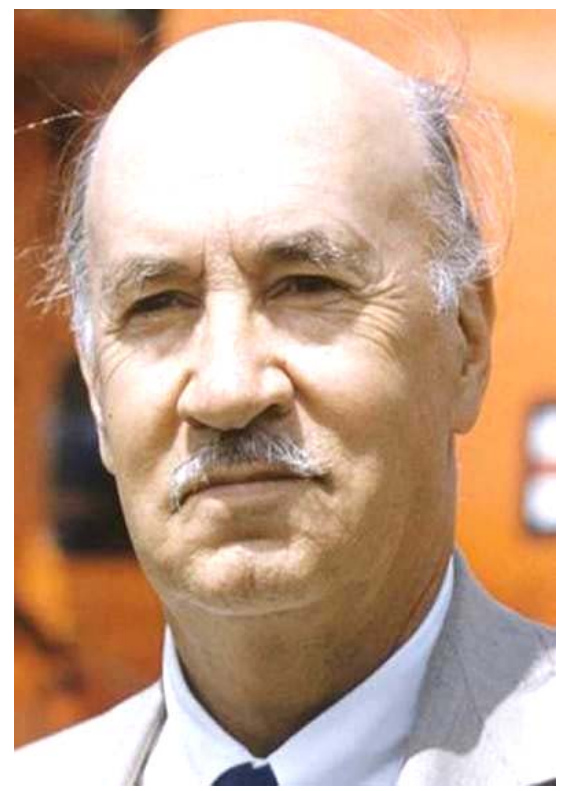

Fig. 10. The world-recognized master of world aviation, aircraft designer I.I. Sikorsky during the heyday of his inventive and engineering activities on American soil (1950s, Easton, Connecticut, USA) [10]

4. Universal human qualities of the aircraft designer I.I. Sikorsky. What kind of person was this outstanding aircraft designer? Medium height, with a soft and even shy manner of speaking and behavior among people [2]. Judging by the data from literary sources $[7,8]$, he possessed remarkable physical and moral strength. He was fond of mountaineering: he conquered a number of mountain peaks of the USA and Canada. He was particularly interested in terrestrial volcanoes. He considered them as «mighty and majestic phenomena of the earthly nature» [2]. He was quite a closed man. Human communication he preferred privacy. Often he went by car to the nature far from the city bustle. He was a caring father. His daughter Tatiana became Professor of sociology at Bridgeport University. His eldest son, Sergey, became design engineer and worked with him at an aircraft manufacturing Company (he went up to the position of Vice-President, that is, deputy for his father). Other sons of I.I. Sikorsky chosen other professions: Nikolay became a violinist, Igor became a lawyer, and George became a mathematician [2]. I.I. Sikorsky considering the patriarchal upbringing in the family of his parents was a deeply religious man. He financially supported the Russian Orthodox Church in America [2]. He was the author of a number of theological works. His head was usually crowned with a favorite «Fedora» hat (see Fig. 1). He and his associates believed that this hat usually brings him good luck both at work and at home.

According to people who knew the outstanding aircraft designer closely, he was exclusively a peaceloving person, and considered the main mission of aviation to be the relief of people's everyday life and work [5]. According to the son of the pioneer of the helicopter industry of the USA Sergey Sikorsky, his father I.I. Sikorsky was a versatile person: a highly qualified engineer, first-class pilot and philosopher [9]. In addition to aviation, he was interested in many things - literature, classical music, history, theology. According to the words of the eldest son Sergey [9]: «... the father did not become a millionaire in the USA. But our family lived comfortably and without material problems».

5. Return of the great aircraft designer I.I. Sikorsky to his alma mater. In 1998, a memorial plaque was opened at the KPI in honor of the famous aircraft designer and its former student [4]. It decorated the brick wall of the building of the former research workshops, in which the young purposeful Igor Sikorsky worked on the creation of his first airplanes. On May 14, 2008 a monument to I.I. Sikorsky was opened (Fig. 11) [11].

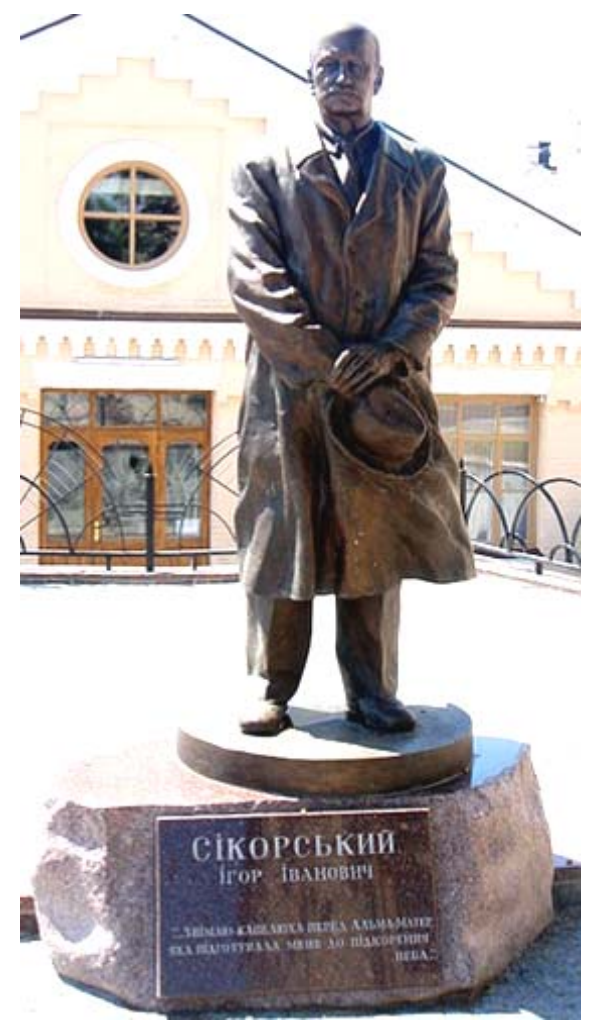

Fig. 11. Monument to the outstanding Ukrainian-American aircraft designer I.I. Sikorsky on the campus of the National Technical University of Ukraine «Kyiv Polytechnic Institute» (2008, Kyiv, Ukraine) [11]

On the marble slab of the pedestal of this world's first monument to an outstanding aircraft designer of the 20th century, the honored artist of Ukraine, sculptor Nikolai Oleinik carved the following words of I.I. Sikorsky, told him in his declining years [4]: «... I take off my hat to the alma mater prepared me for the conquest of the sky»). Rector of the KPI, Academician of the National Academy of Sciences of Ukraine M.Z. Zgurovsky at the opening of the monument to the former talented student of the KPI, who has become a world-famous aircraft designer, noted that «... I.I. Sikorsky will inspire young polytechnics to fulfill their dreams with his image, example and his fate» [11]. On August 26, 2016 the NTUU «KPI» (Fig. 12) became known as the Igor Sikorsky National Technical University of Ukraine «Kyiv Polytechnic Institute» [12]. The corresponding order No. 992 of August 17, 2016 was signed by the Minister of Education and Science of Ukraine L.M. Hrynevych [12]. 


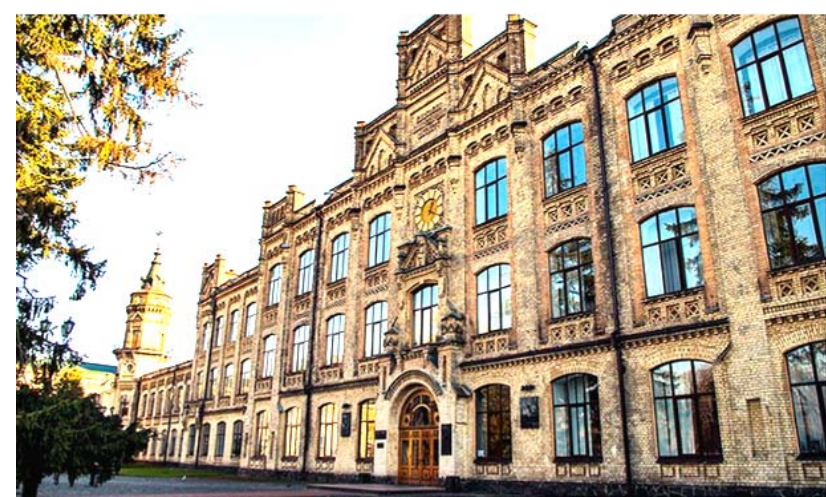

Fig. 12. General view of the main academic building of the Igor Sikorsky NTUU «KPI» (2016, Kyiv, Ukraine) [12]

So the great compatriot and aircraft designer of modernity, after his death, returned to his native city of Kyiv and to his unforgettable alma mater.

Conclusions. Many scientific and technical achievements in the field of world aircraft and helicopter design are connected with the name of our famous compatriot Igor Ivanovich Sikorsky, who became one of the largest aircraft designers of the 20th century. He developed and built 17 basic types of airplanes and 18 basic types of helicopters working on piston and gas turbine engines in Russia and the USA. He became the «father» of the world helicopter industry. Helicopters developed by him for the first time in the world flied (with air refueling) through the Atlantic (S-61, 1967) and Pacific (S-65, 1970) oceans. One of the indicators of the reliability of the aircraft designs created by him is that until now the US Presidents fly helicopters with the words «Sikorsky» on board. Outstanding Ukrainian-American aircraft designer I.I. Sikorsky played a crucial role in the formation and development of world aviation. For his aircrafts, he was awarded many honorary titles and awards. The main reward to him, nevertheless, remains the gratitude of people from all continents of our planet for peaceful purposes using the flying machines created by him and the principles of their design and construction developed by him.
1. Available at: https://www.pravmir.ru/igor-ivanovichsikorskij-geroj-izgnannik-otec-aviacii (accessed 11 May 2017). (Rus).

2. Available

https://www.maximonline.ru/longreads/photogallery/ article/ch elovek-s-vintom (accessed 9 May 2017). (Rus).

3. Available at: http://kpi.ua/ru/sikorsky (accessed 19 October 2017). (Rus).

4. Available at: http://kpi.ua/ru/node/7895 (accessed 29 July 2017). (Rus).

5. Available at: https://history.vn.ua/book/person/80.html (accessed 29 January 2018). (Rus).

6. Available at: http://www.tvc.ru/news/show/id/69580 (accessed 22 February 2018). (Rus).

7. Available at: http://to-name.ru/biography/igor-sikorskij.htm (accessed 10 March 2018). (Rus).

8. Katyshev G.I., Mikheev M.R. Aviakonstruktor Igor Ivanovich Sikorskiy. 1889-1972 [Aircraft Designer Igor Ivanovich Sikorsky. 1889-1972]. Moscow, Nauka Publ., 1989. 176 p. (Rus).

9. Available at: https://fakty.ua/149040-syn-legendarnogoaviakonstruktora-igorya-sikorskogo (accessed 8 May 2018). (Rus).

10. Available at: http://www.tvc.ru/news/show/id/69580 (accessed 18 April 2018). (Rus).

11. Available at: http://kpi.ua/ru/node/950 (accessed 23 May 2018). (Rus).

12. Available at: https://gordonua.com/news/society/kievskiypoliteh-nicheskiy-institut-poluchil-imya-sikorskogo147197.html (accessed 10 June 2018). (Rus).

Received 01.10.2018

M.I. Baranov, Doctor of Technical Science, Professor,

Scientific-\&-Research Planning-\&-Design Institute «Molniya», National Technical University «Kharkiv Polytechnic Institute», 47, Shevchenko Str., Kharkiv, 61013, Ukraine, phone +380 577076841

e-mail: baranovmi@kpi.kharkov.ua

How to cite this article:

Baranov M.I. An anthology of the distinguished achievements in science and technique. Part 47: Aircraft designer Igor Sikorsky and his accomplishments in design of airplanes and helicopters. Electrical engineering \& electromechanics, 2019, no.1, pp. 3-8. doi: 10.20998/2074-272X.2019.1.01. 